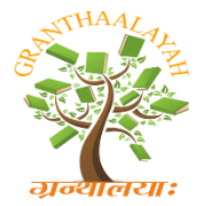

\author{
INTERNATIONAL JOURNAL OF RESEARCH - \\ GRANTHAALAYAH \\ A knowledge Repository
}

Social

\title{
PROMOTING EDUCATIONAL STAKEHOLDER VOLUNTEERISM IN THE DIVISION OF BATANGAS CITY, PHILIPPINES
}

\author{
Ted Ian D. Jungay ${ }^{1}$, Romeo M. Guillo, Jr ${ }^{2}$ \\ ${ }^{* 1}$ Banaba National High School, Department of Education \\ ${ }^{2}$ College of Teacher Education, Batangas State University
}

\begin{abstract}
This study aimed to promote volunteerism among educational stakeholders to support public secondary school programs in the Division of Batangas City. It determined the projects, activities and programs (PAP's) undertaken by the public schools that need the assistance of the stakeholders, and the extent of the stakeholders' support along school affairs- its organizational set and policies, projects and activities, student services and facilities. It also delved about the problems met by the public schools in promoting volunteerism among their stakeholders. The study made use of descriptive method with the survey questionnaire, interview and documentary analysis as data gathering instruments. The respondents were 18 school heads, 258 teachers and 74 parents of the 18 public secondary schools. The study revealed that the respondents often supported school projects, activities and programs undertaken by the school. Extra-curricular activities for music and arts were seldom supported. Educational stakeholders also supported school organization set up, policies, school projects, student services and school facilities to a great extent. The main problem encountered in the promotion of volunteerism among stakeholders was that many of the community people come from low-income families thus they hardly provide financial assistance to school which was rated moderately serious.
\end{abstract}

Keywords: Promotion; Stakeholder; Volunteerism; School Projects.

Cite This Article: Ted Ian D. Jungay, and Romeo M. Guillo, Jr (2019). "PROMOTING EDUCATIONAL STAKEHOLDER VOLUNTEERISM IN THE DIVISION OF BATANGAS CITY, PHILIPPINES." International Journal of Research - Granthaalayah, 7 (5), 10-20. https://doi.org/10.29121/granthaalayah.v7.i5.2019.818.

\section{Introduction}

Education has been a foundation of everything particularly on man's pursuit for an answer to his problem. It is everybody's ultimate opportunity for holistic growth and development to become fruitful and productive citizen. The role of education in national development is indispensable. It has been looked into as the means of alleviating poverty, decreasing criminalities, increasing economic benefits and ultimately uplifting the standard of living of every Filipino (Durban, 2008). 
At the turn of the 21 st Century however, much expectation is shouldered to schools. The core of educational reforms shifted to global demands other than national improvements. The world has become smaller due to the advent of technological innovations, thus global competition intensified. Eventually, the demand for world-class graduates became more pronounced. Students nowadays will need goes well beyond the basics. They should be knowledgeable about the world, be able to communicate in languages other than English and be globally competitive. Such is the utmost concern of every educational institution- to provide quality education for its students, however, with the complexity of the problems that besetting the Philippine educational system today, solutions are still far from a reality.

Countries in Southeast Asia, like the Philippines, Laos, Cambodia and Vietnam, face educational challenges associated with being a developing nation with limited resources. The Asian Development Bank (Chapman and Adams, 2008) noted that same countries have poor school facilities, insufficiently relevant curriculum, lack of textbooks, insufficient teacher training, limited of new teaching methods and have high pupil-to-teacher ratio of about 40 to 60 pupils per teacher.

Likewise in the country, the government on its part has been continuously investing so much resource into the education sector. However, the assistance given by government to address the demands of growing student populace is still meager. Schools in the rural areas do not receive much support from the government. Most elementary and secondary schools in the country lack of well-ventilated classrooms, functional school facilities and more competent teachers, while state colleges are empowered to generate their income in order that they can manage their finances and not depend so much from government subsidies. Limited resources complicate school missions to meet the needs of the students. Thus, the so much-awaited quality instruction is at stake. Most public rural schools are left behind in nowhere; their school heads are challenged to seek somebody who might assist them and prop up school inadequacies.

Since the government alone cannot suffice the increasing demands of public schools and the aforementioned educational crises hinder quality school performance, leadership and relationship skills of school heads are always challenged. As independent manager to run a school system, the questions always seem too difficult to engage; how he shall generate funds to support school projects and activities and who could be those persons to share burden in gaining legitimacy and support.

A school head who is left working alone in making major decisions in running a school system may experience predicament and discomfort particularly in finding means to meet the pressing demands of students and continuance of pending projects. Undeniably, schools need external partners to assist school administrators and teachers in sustaining the life of school affairs throughout times to ensure quality education for students.

Fortunately, these challenges were finally answered when School-Based Management (SBM) was introduced and embraced by most of the public schools nationwide. Adhered in RA 9155, SBM mandates the implementation of shared governance in the administration of public schools. It also grants authority, accountability and responsibility to school heads to develop school improvement 
programs by fostering active school-family-community linkages. By this educational legislation, school-stakeholders' partnership is bolstered.

This research study advocates the necessity of involving stakeholders and other groups of people in sustaining and supporting school affairs for its survival and improvement. The response of schools to demands for higher levels of performance must include the involvement of many stakeholders in determining, executing, and supporting better ways to deliver educational services, and organizing work settings and organizational units for higher performance. Those highperforming schools are able to accomplish their mission by continually improving their capacity to deliver highly valued outcomes to their stakeholders, and in return to continue to receive the sources required for ongoing performance.

Thus, organizational survival is related to the value of outcomes as determined by the stakeholders, who provide the resource stream that supports the organization, not by the organizational members only. Adhering with School Based Management principle, one school head should employ a variety of mechanism for different purposes and appropriately involve many people and different stakeholder groups in managing and improving the school.

Information sharing and accountability systems of stakeholders are key component of highinvolvement organization. Schools will improve only if they establish appropriate forums for participation, and continually involve people in many activities of self-management and improvement (Katz and Kahn, 2006).

The school head's primary responsibility is to keep the school on track. For instance, for a school to survive, it must raise funds, whether from government support or other source, to pay salaries and wages, maintenance and operating expenses. So with proper collaboration with the community and other stakeholders, a school head may effectively deal with school insufficiencies.

As being stated in Republic Act No. 10533 Sec. 5, to achieve an effective enhanced basic education curriculum, DepEd shall undertake consultations with other national government agencies and other stakeholders including but not limited to the Department of Labor and Employment (DOLE), the Professional Regulation Commission (PRC), the private and public schools associations, the national student organizations, the national teacher organizations, the parent-teachers associations and the chambers of commerce on matters affecting the concerned stakeholders.

Whatever assistance and support these stakeholders may offer to school nevertheless how big or small they are, somehow may lessen educational problems and improve schools throughout the region. It is about time to look for committed partners whom the school may rely upon during distress and inadequacy. However, the school should take the initiative to wake up sleeping partners who are untapped and indifferent to school growth and improvement. Volunteerism from among all sectors shall be emphasized and encouraged to ensure sustainable growth and development in education as what School Governing Council holds.

Seemingly, although school missions are inspired by SBM guiding principles and loopholes are nowhere to be found in the existing policies on school-stakeholders partnership, still many school heads are inexperienced and unaware of its appropriate implementation and promotion and how to 
exploit available community resources for school improvement. For instance, many school heads work alone in making of the SIP, AIP and the APP without consultation from parents and other external stakeholders. Some school heads never engage parents and teachers in school-decision making in solving school issues and problems while some school principals never include stakeholders as members of advisory group in formulating school policies, objectives and regulations.

Those are just simple steps to involve stakeholders in school improvement processes which may yield positive results to enhance volunteerism among them that some school managers forgot. Educational stakeholder volunteerism should be promoted and strengthened among public schools to form collaboration and partnership of internal and external stakeholders to ensure success in educational undertakings and yield remarkable learning outcomes.

The foregoing reasons prompted the researcher to write this research work aimed to help school managers to further enhance the promotion of stakeholder volunteerism in public schools to support their projects and activities. At the end of the study, the researcher proposed feasible measures to encourage more educational stakeholders to support projects, activities and programs (PAPs) of public schools in the Division of Batangas City.

Moreover, this study also determined the projects and activities undertaken by the schools that need assistance of the stakeholders, the assessment of the respondents about the extent of stakeholders' support to some school affairs particularly the school organizational set up and policies, school projects and activities, student services, and school facilities. This also delved about some problems met by public schools in requesting assistance from their potential stakeholders which became the bases of this study's output.

\section{Materials and Methods}

This study aimed to promote volunteerism among educational stakeholders to support public secondary school programs in the Division of Batangas City. Specifically, it determined the projects, activities and programs (PAP's) undertaken by the public schools that need the assistance of the stakeholders, and the extent of the stakeholders' support along school affairs- its organizational set and policies, projects and activities, student services and facilities. It also delved about the problems met by the public schools in promoting volunteerism among their stakeholders. Measures were proposed to enhance the promotion of volunteerism among educational stakeholders.

The study made use of descriptive method with the survey questionnaire, interview and documentary analysis as main data gathering instruments. The respondents were 18 school heads, 258 teachers and 74 parents of the 18 public secondary schools in the Division of Batangas City. Frequency, ranking, weighted mean, composite mean, F-test and Scheffe' Test were the statistical treatment tools utilized in the study.

\section{Results and Discussions}

From the data gathered, the following findings were obtained. 


\subsection{Projects, Activities and Programs (PAPs) Undertaken by the School}

There were a total of 36 projects, activities and programs cited in the study. Out of them, the least supported PAPs that need the assistance of stakeholders were extracurricular activities for music and arts. Among them was school band, seldom supported by the stakeholders that got the lowest weighted mean of 2.10, followed respectively by school choir, seldom supported with a weighted mean of 2.18, school dance troupe, often supported with a weighted mean of 2.56 and scholarship program and school livelihood program that both earned the weighted means of 2.82 which were often supported by the stakeholders.

Table 1: Projects, Activities and Programs (PAPs) Undertaken by the School

\begin{tabular}{|c|c|c|}
\hline Items & Weighted Mean & Verbal Interpretation \\
\hline 1. Brigada Eskwela (School Brigade) & 3.61 & Very Often \\
\hline 2. Homeroom Improvement and Development & 3.32 & Often \\
\hline $\begin{array}{l}\text { 3. Construction and repair of school buildings and } \\
\text { facilities }\end{array}$ & 2.96 & Often \\
\hline 4. Acquisition of teaching and learning materials & 3.07 & Often \\
\hline 5. Curriculum Implementation & 3.38 & Often \\
\hline 6. Fund Raising Campaign & 2.88 & Often \\
\hline 7. PTA, SSG and Alumni Projects & 3.15 & Often \\
\hline 8. Religious Related Activities & 3.04 & Often \\
\hline 9. School Beautification & 3.36 & Often \\
\hline 10. School Reading Program & 3.13 & Often \\
\hline 11. Adopt-a-School Program & 3.01 & Often \\
\hline 12. Scholarship Program/ Project C-Care & 2.82 & Often \\
\hline 13. School Guidance Program & 3.12 & Often \\
\hline 14. Feeding Program & 3.06 & Often \\
\hline 15. Sports and Recreation Program & 2.99 & Often \\
\hline 16. School Risk Reduction Program & 3.05 & Often \\
\hline 17. School Livelihood Program & 2.82 & Often \\
\hline 18. Student at Risk Drop Out Reduction Program & 3.05 & Often \\
\hline 19. Alternative Learning System (ALS) & 2.85 & Often \\
\hline 20. School Based Drug Abuse Prevention Program & 3.07 & Often \\
\hline 21. School In-service Trainings & 3.31 & Often \\
\hline 22. Nutrition Month & 3.21 & Often \\
\hline 23. Buwan ng Wika (Language Month) & 3.17 & Often \\
\hline 24. United Nation (UN) Week & 2.82 & Often \\
\hline 25. English Festival & 3.02 & Often \\
\hline 26. Science Fair/Camp & 3.03 & Often \\
\hline 27. School Intramurals & 3.26 & Often \\
\hline 28. Education Week & 3.36 & Often \\
\hline 29. Teachers' Day Celebration & 3.46 & Often \\
\hline 30. Forest Protection and Tree Planting Program & 2.88 & Often \\
\hline 31. School Clean and Green Campaign & 3.35 & Often \\
\hline 32. Scouting Program & 3.10 & Often \\
\hline
\end{tabular}


DOI: 10.5281/zenodo.3234494

\begin{tabular}{|l|l|l|}
\hline 33. School Dance Troupe & 2.56 & Often \\
\hline 34. School Band & 2.10 & Seldom \\
\hline 35. School Choir & 2.18 & Seldom \\
\hline 36. School Paper Publication & 3.13 & Often \\
\hline Composite Mean & $\mathbf{3 . 0 5}$ & Often \\
\hline
\end{tabular}

\subsection{Extent of Support along School Affairs}

\subsubsection{School Organizational Set Up and Policies}

The results revealed the that average composite mean for each of the set of responses assessed by the stakeholders were 3.39 among school heads, 3.35 among teachers and 2.87 among parents. Stakeholders supported school organization set up and policies to a great extent with the general composite mean of 3.20 .

Table 2: Extent of Stakeholders' Support along the School Organizational Set Up and Policies

\begin{tabular}{|l|l|l|l|l|l|l|}
\hline \multirow{2}{*}{ Indicators } & \multicolumn{2}{|c|}{ School Heads } & \multicolumn{2}{|c|}{ Teachers } & \multicolumn{2}{c|}{ Parents } \\
\cline { 2 - 9 } & WM & VI & WM & VI & WM & VI \\
\hline 1. Advocate school vision and mission. & 3.56 & VGE & 3.47 & GE & 2.89 & GE \\
\hline $\begin{array}{l}\text { 2. Engage in school-decision making in solving } \\
\text { school issues and problems. }\end{array}$ & 3.44 & GE & 3.12 & GE & 2.67 & GE \\
\hline $\begin{array}{l}\text { 3. Serve as a member of advisory group in } \\
\text { formulating school policies, objectives and } \\
\text { regulations. }\end{array}$ & 3.44 & GE & 3.03 & GE & 2.46 & ME \\
\hline 4. Recognize and respect school authorities. & 3.61 & VGE & 3.64 & VGE & 3.24 & GE \\
\hline $\begin{array}{l}\text { 5. Provide helpful feedbacks for school } \\
\text { improvement. }\end{array}$ & 3.33 & GE & 3.32 & GE & 2.81 & GE \\
\hline $\begin{array}{l}\text { 6. Support curriculum implementation. } \\
\text { 7. Follow existing school policies and } \\
\text { regulations. }\end{array}$ & 3.44 & GE & 3.53 & VGE & 2.89 & GE \\
\hline $\begin{array}{l}\text { 8. Promote the general welfare of students, } \\
\text { teachers and school personnel. }\end{array}$ & 3.50 & VGE & 3.56 & VGE & 2.83 & GE \\
\hline $\begin{array}{l}\text { 9. Check school mismanagement and abuse of } \\
\text { authority. }\end{array}$ & 3.11 & GE & 3.02 & GE & 2.69 & GE \\
\hline $\begin{array}{l}\text { 10. Collaborate with the school to uphold } \\
\text { teamwork and unity. }\end{array}$ & 3.39 & GE & 3.39 & GE & 3.15 & GE \\
\hline 11. Herald school accomplishments. & 3.11 & GE & 3.32 & GE & 2.81 & GE \\
\hline $\begin{array}{l}\text { 12. Help school in establishing linkages among } \\
\text { key sectors in the community. }\end{array}$ & 3.11 & GE & 3.22 & GE & 2.83 & GE \\
\hline Composite Mean & $\mathbf{3 . 3 9}$ & GE & $\mathbf{3 . 3 5}$ & GE & $\mathbf{2 . 8 7}$ & GE \\
\hline
\end{tabular}

Legend: VGE - Very Great ExtentGE - Great Extent 


\subsubsection{School Projects and Activities}

The average composite mean for each of the set of responses assessed by the stakeholders were 3.24 among school heads, 3.33 among teachers and 2.82 among parents. Stakeholders supported school projects and activities to a great extent with the general composite mean of 3.13.

Table 3: Extent of Stakeholders' Support along School Projects and Activities

\begin{tabular}{|c|c|c|c|c|c|c|}
\hline \multirow[t]{2}{*}{ Items } & \multicolumn{2}{|c|}{ School Heads } & \multicolumn{2}{|c|}{ Teachers } & \multicolumn{2}{|c|}{ Parents } \\
\hline & WM & VI & WM & VI & WM & VI \\
\hline $\begin{array}{l}\text { 1. Provide means for extracurricular activities of } \\
\text { students. }\end{array}$ & 3.00 & GE & 3.27 & GE & 2.98 & GE \\
\hline $\begin{array}{l}\text { 2. Assist the school administrators in planning } \\
\text { school activities. }\end{array}$ & 3.17 & GE & 3.14 & $\mathrm{GE}$ & 2.72 & GE \\
\hline 3. Participate in Brigada Eskwela activities. & 3.22 & GE & 3.63 & VGE & 2.96 & $\mathrm{GE}$ \\
\hline 4. Join PTA and Alumni programs and activities. & 3.00 & GE & 3.41 & GE & 2.76 & GE \\
\hline $\begin{array}{l}\text { 5. Monitor school performance and suggest } \\
\text { intervention programs. }\end{array}$ & 3.17 & GE & 3.16 & GE & 2.33 & $\mathrm{ME}$ \\
\hline 6. Attend calendar activities of the school. & 3.22 & GE & 3.42 & GE & 3.00 & GE \\
\hline $\begin{array}{l}\text { 7. Provide financial assistance for school projects } \\
\text { and activities. }\end{array}$ & 3.22 & GE & 3.02 & GE & 2.59 & GE \\
\hline 8. Attend PTA meetings, forum and consultations. & 3.50 & VGE & 3.41 & GE & 3.09 & $\mathrm{GE}$ \\
\hline $\begin{array}{l}\text { 9. Support seminars and trainings for teachers, } \\
\text { parents, students and school personnel. }\end{array}$ & 3.56 & VGE & 3.50 & VGE & 2.80 & GE \\
\hline $\begin{array}{l}\text { 10. Participate in the civic and social activities in } \\
\text { the community launched by the school. }\end{array}$ & 3.28 & GE & 3.28 & GE & 2.91 & $\mathrm{GE}$ \\
\hline $\begin{array}{l}\text { 11. Participate in school environmental protection } \\
\text { drive. }\end{array}$ & 3.17 & GE & 3.33 & $\mathrm{GE}$ & 2.80 & GE \\
\hline $\begin{array}{l}\text { 12. Get involved in realizing school goals and } \\
\text { projects. }\end{array}$ & 3.44 & GE & 3.36 & $\mathrm{GE}$ & 2.89 & GE \\
\hline Composite Mean & 3.24 & GE & 3.33 & GE & 2.82 & GE \\
\hline
\end{tabular}

\subsubsection{Student Services}

The results revealed that the average composite mean for each of the set of responses assessed by the stakeholders were 3.32 among school heads, 3.17 among teachers and 2.82 among parents. Stakeholders supported the student services to a great extent with the general composite mean of 3.10 .

Table 4: Extent of Stakeholders' Support along Student Services

\begin{tabular}{|l|c|c|c|c|c|c|}
\hline Items & \multicolumn{2}{|c|}{ School Heads } & \multicolumn{2}{|c|}{ Teachers } & \multicolumn{2}{|c|}{ Parents } \\
\cline { 2 - 7 } & WM & VI & WM & VI & WM & VI \\
\hline $\begin{array}{l}\text { 1. Establish better cooperation with the school in } \\
\text { maintaining a child- friendly school environment. }\end{array}$ & 3.50 & VGE & 3.45 & GE & 2.98 & GE \\
\hline 2. Help school maintain peace and order. & 3.44 & GE & 3.45 & GE & 3.00 & GE \\
\hline 3. Help in establishing efficient school canteen. & 3.39 & GE & 3.23 & GE & 2.76 & GE \\
\hline
\end{tabular}


DOI: 10.5281/zenodo.3234494

\begin{tabular}{|l|l|l|l|l|l|l|}
\hline $\begin{array}{l}\text { 4. Work with school to prevent students from } \\
\text { negative influence of vices and drug addiction. }\end{array}$ & 3.61 & VGE & 3.31 & GE & 2.87 & GE \\
\hline $\begin{array}{l}\text { 5. Collaborate with the school in rendering better } \\
\text { guidance program for the students. }\end{array}$ & 3.61 & VGE & 3.24 & GE & 2.94 & GE \\
\hline $\begin{array}{l}\text { 6. Assist the school in providing sanitary measures } \\
\text { to students. }\end{array}$ & 3.56 & VGE & 3.22 & GE & 3.07 & GE \\
\hline 7. Help school in generating scholarship for students. & 3.00 & GE & 3.00 & GE & 2.69 & GE \\
\hline $\begin{array}{l}\text { 8. Help school in providing efficient sports and } \\
\text { recreational activities for students. }\end{array}$ & 3.11 & GE & 3.05 & GE & 2.65 & GE \\
\hline $\begin{array}{l}\text { 9. Assist school in providing venues for student } \\
\text { community immersions. }\end{array}$ & 3.00 & GE & 2.93 & GE & 2.72 & GE \\
\hline $\begin{array}{l}\text { 10. Help school in achieving adequate dental and } \\
\text { medical services to students. }\end{array}$ & 3.00 & GE & 2.78 & GE & 2.56 & GE \\
\hline Composite Mean & $\mathbf{3 . 3 2}$ & GE & $\mathbf{3 . 1 7}$ & GE & $\mathbf{2 . 8 2}$ & GE \\
\hline
\end{tabular}

Legend: VGE - Very Great Extent GE- Great Extent

\subsubsection{School Facilities}

The average composite mean for each of the set of responses assessed by the stakeholders were 3.21 among school heads, 2.89 among teachers and 2.28 among parents. Stakeholders supported the school facility improvements to a great extent with the general composite mean of 2.89 .

Table 5: Extent of Stakeholders' Support along School Facilities

\begin{tabular}{|l|l|l|l|l|l|l|}
\hline Items & \multicolumn{2}{l}{ School Heads } & \multicolumn{2}{|c|}{ Teachers } & \multicolumn{2}{|c|}{ Parents } \\
\cline { 2 - 7 } & WM & VI & WM & VI & WM & VI \\
\hline $\begin{array}{l}\text { 1. Provide financial resources for the repair and } \\
\text { construction of school buildings, classrooms, } \\
\text { laboratories, fence, parks, etc. }\end{array}$ & & & & & & \\
\hline $\begin{array}{l}\text { 2. Help the school in procuring textbooks and } \\
\text { learning materials. }\end{array}$ & 3.33 & $\mathrm{GE}$ & 2.71 & $\mathrm{GE}$ & 2.41 & $\mathrm{ME}$ \\
\hline $\begin{array}{l}\text { 3. Help improve school beautification and } \\
\text { cleanliness. }\end{array}$ & 3.44 & $\mathrm{GE}$ & 3.44 & $\mathrm{GE}$ & 2.85 & $\mathrm{GE}$ \\
\hline $\begin{array}{l}\text { 4. Help the school in soliciting local government and } \\
\text { private aids to purchase site or construct additional } \\
\text { building and facilities. }\end{array}$ & 3.22 & $\mathrm{GE}$ & 2.78 & $\mathrm{GE}$ & 2.54 & $\mathrm{GE}$ \\
\hline $\begin{array}{l}\text { 5. Help school in maintaining sports facilities and } \\
\text { amenities for the students. }\end{array}$ & 3.17 & $\mathrm{GE}$ & 2.72 & $\mathrm{GE}$ & 2.52 & $\mathrm{GE}$ \\
\hline $\begin{array}{l}\text { 6. Contribute money, donate materials and volunteer } \\
\text { services during Brigada Eskwela. }\end{array}$ & 3.22 & $\mathrm{GE}$ & 2.98 & $\mathrm{GE}$ & 2.72 & $\mathrm{GE}$ \\
\hline $\begin{array}{l}\text { 7. Provide school with vital information on available } \\
\text { community resources and wealth. }\end{array}$ & 3.06 & $\mathrm{GE}$ & 2.85 & $\mathrm{GE}$ & 2.43 & $\mathrm{ME}$ \\
\hline $\begin{array}{l}\text { 8. Assist school in maintaining sanitary measures to } \\
\text { maintain clean toilets, lavatories, water tanks and } \\
\text { waste facilities. }\end{array}$ & 3.33 & $\mathrm{GE}$ & 3.05 & $\mathrm{GE}$ & 2.72 & $\mathrm{GE}$ \\
\hline $\begin{array}{l}\text { 9. Help school to recuperate from facility loss after } \\
\text { calamity devastation. }\end{array}$ & 3.11 & $\mathrm{GE}$ & 2.93 & $\mathrm{GE}$ & 2.54 & $\mathrm{GE}$ \\
\hline
\end{tabular}


DOI: 10.5281/zenodo.3234494

\begin{tabular}{|l|l|l|l|l|l|l|}
\hline $\begin{array}{l}\text { 10. Provide financial assistance or equipment in } \\
\text { furnishing learning facilities and school laboratories. }\end{array}$ & & GE & 2.74 & GE & 2.28 & GE \\
\hline Composite Mean & $\mathbf{3 . 2 1}$ & GE & $\mathbf{2 . 8 9}$ & GE & $\mathbf{2 . 5 6}$ & GE \\
\hline
\end{tabular}

Legend: VGE - Very Great Extent GE - Great Extent ME - Moderate Extent

\subsection{Comparison of the Assessments on the Extent of Support along School Affairs}

The assessments of the three groups of respondents differed as to the extent of their support along school organizational set up and policies, school projects and activities, student services and improvement of school facilities. The registered computed F-values ranging from 47.074 to 115.699 were greater than the critical p-value of 0.000 which were all lower than .05 level of significance, at 2 degree of freedom between and 327 degree of freedom among. This led in the rejection of the null hypothesis.

To identify the pairs where the significant differences occurred, the respondents differed in school organizational set and policies where groups of school heads and parents earned the highest mean difference of 0.519 ; they also differed in school projects and activities where groups of teachers and parents earned the highest mean difference of 0.507. Moreover, extent of support along student services and facilities improvement had different assessments too between the groups of school heads and parents that got the highest mean differences of 0.498 and 0.652 which were greater than the p-value of 0.000 at .05 level of significance.

Table 6: Comparison of the Responses on the Extent of Stakeholders' Support along the Four Schools Affairs

\begin{tabular}{|l|l|l|l|l|}
\hline Profile Variable & Fc & $\mathbf{p}-$ value & Decision on H0 & Interpretation \\
\hline $\begin{array}{l}\text { School Organizational Set-up } \\
\text { and Policies }\end{array}$ & 115.699 & 0.000 & Reject & Significant \\
\hline School Projects and Activities & 108.683 & 0.000 & Reject & Significant \\
\hline Student Services & 47.074 & 0.000 & Reject & Significant \\
\hline School Facilities & 52.384 & 0.000 & Reject & Significant \\
\hline
\end{tabular}

\subsection{Problems Met by Public Schools in Promoting Volunteerism of Stakeholders}

The main problem encountered by the public secondary schools in the Division of Batangas City was many of the community people come from low-income families thus they hardly provide financial assistance to school. This was rated moderately serious by the respondents and it obtained the highest weighted mean of 2.61. Following to it was stakeholder in the community were busy with their works, thus they neglected school activities. Rated slightly serious by school heads, teachers and parents, it obtained a weighted mean of 2.39. Third among them was stakeholders were apathetic and indifferent towards school progress and improvement with a weighted mean of 2.30. School heads, teachers and parents rated it slightly serious. School heads, teachers and parents rated the entire problems met by public schools in promoting volunteerism of stakeholders as slightly serious with an average composite mean of 2.01 . 
Table 7: Problems Met by Public Schools in Promoting Volunteerism of Stakeholders

\begin{tabular}{|l|l|l|}
\hline Items & Weighted Mean & Verbal interpretation \\
\hline $\begin{array}{l}\text { 1. Stakeholders are apathetic and indifferent towards } \\
\text { school progress and improvement. }\end{array}$ & 2.30 & Slightly Serious \\
\hline $\begin{array}{l}\text { 2. Many of the community people come from low- } \\
\text { income families. }\end{array}$ & 2.61 & Moderately Serious \\
\hline $\begin{array}{l}\text { 3. Stakeholders in the community are busy with their } \\
\text { works. }\end{array}$ & 2.39 & Slightly Serious \\
\hline 4. Stakeholders have lost their trust in school. & 1.87 & Slightly Serious \\
\hline $\begin{array}{l}\text { 5. Stakeholders are not properly oriented about their } \\
\text { roles. }\end{array}$ & 2.08 & Slightly Serious \\
\hline $\begin{array}{l}\text { 6. The school administrators do not have the initiative } \\
\text { and charisma to attract potential stakeholders. }\end{array}$ & 1.93 & Slightly Serious \\
\hline $\begin{array}{l}\text { 7. Distance from school and transportation problem } \\
\text { make the parents and community people difficult to } \\
\text { attend school meetings and programs. }\end{array}$ & 2.15 & Slightly Serious \\
\hline $\begin{array}{l}\text { 8. Administrators do not include the stakeholders in } \\
\text { school planning and program implementation. }\end{array}$ & 1.85 & Slightly Serious \\
\hline 9. Stakeholders don't like the school Management style. & 1.85 & Slightly Serious \\
\hline $\begin{array}{l}\text { 10. There is lack of coordination and cooperation } \\
\text { between school and PTCA members. }\end{array}$ & 1.92 & Slightly Serious \\
\hline $\begin{array}{l}\text { 11. School becomes politically involved when asking } \\
\text { assistance from local government. }\end{array}$ & 1.87 & Slightly Serious \\
\hline $\begin{array}{l}\text { 12. Stakeholders are not satisfied with the school } \\
\text { performance and output. }\end{array}$ & 1.82 & Slightly Serious \\
\hline $\begin{array}{l}\text { 13. Stakeholders and community people are usually shy } \\
\text { to attend school programs and activities. }\end{array}$ & 1.94 & 1.77 \\
\hline $\begin{array}{l}\text { 14. School creates unfavourable environment that } \\
\text { discourages stakeholder involvement. }\end{array}$ & 1.83 & Slightly Serious \\
in. The school governing council is ineffective and & 1.83 Serious \\
\hline
\end{tabular}

\subsection{Proposed Measures for Enhancing the Promotion of Stakeholders' Volunteerism}

A proposed measures have been conceptualized to enhance the promotion of volunteerism among educational stakeholders to support school projects, activities and programs (PAPs). It is consisted of measures, objectives, strategies, time frame, persons involved and expected outcomes to increase involvement and support of stakeholders among areas of concern, namely school organizational set up and policies, school projects and activities, student services and school facility improvements. Proposed measures highlighted feasible strategies to address the least supported PAPs as correlates with stakeholders' volunteerism.

\section{Conclusions and Recommendations}

Extracurricular activities for music and arts such as school band, school choir and school dance troupe were among the PAPs undertaken by public schools that needed the assistance of 
stakeholders. School heads, teachers and parents supported school organizational set up and policies, projects, activities, student services and school facility improvement to a great extent. There are significant differences among the assessments of school heads, teachers and parents on the extent of their support along school organizational set up, school policies, projects, activities, student services and school facility improvements. Many of the community people come from low-income families is the main problem encountered by public secondary schools in promoting stakeholders' volunteerism.

From the findings and conclusions of the study, the following recommendations are offered such that the proposed measures may be shown to peers, supervisors, and other school authorities for further suggestions. Wide implementation of the study's output is recommended to enhance the promotion of volunteerism among educational stakeholders in the public schools. A similar study may be conducted to really intensify the volunteerism of educational stakeholders to support school projects, activities and programs.

\section{References}

[1] Durban, S. Responsibility and Control. A Theory of Man's Responsibility. Cambridge University Press. 2008

[2] Katz \& Kahn, Changing Leadership for Changing Times. Buckingham: Open University Press.2006.

[3] Chapman \& Adams. Generating Curriculum and Instructional Reforms. Educational Administration Quarterly, 42, 207-209.University of Minnesota- Twin Cities. 2008.

*Corresponding author.

E-mail address: tjungay_20 @yahoo.com.ph/bsuguillo @yahoo.com 